\title{
GAMBARAN ELEKTROKARDIOGRAM PADA PASIEN DM TIPE 2 DI POLIKLINIK ENDOKRIN BLU RSUP PROF. DR. R. D. KANDOU MANADO
}

\author{
${ }^{1}$ Fikri H. Maradjabessy \\ ${ }^{2}$ Starry H. Rampengan \\ ${ }^{2}$ Yuanita Asri Langi
}

\author{
${ }^{1}$ Kandidat Skripsi Fakultas Kedokteran Universitas Sam Ratulangi Manado \\ ${ }^{2}$ Bagian Ilmu Penyakit Dalam Fakultas Kedokteran Universitas Sam Ratulangi \\ Manado
}

\begin{abstract}
There were so many theories and hypotheses association between DM type 2 and cardiovascular diseases (CVD). 5,1 million mortality due to DM (3/4 associated to CVD as DM complication). Early diagnosis of CVD on DM type 2 is crucial, such as ECG sign. The study population, derived from DM type 2 patients visited in Policlinic of Endocrine Prof. Dr. R. D. Kandou Manado hospital for 1 month (September 2014). We design a descriptive retrospective study consisting of non-randomly selected DM type 2 patients medical record with an ECG traces. We evaluated the altered ECG of DM type 2 patients. During the study, there were $53 \mathrm{LAH} / \mathrm{LAE}$ traces, coroner vascular diseases 41 traces (18 ischemic myocardium traces, 23 old myocardium infarct traces), bundle branch block (12 LAHB/LAFB, 7 RBBB complete, 3 RBBB incomplete, 1 LBBB traces), 9 LVH traces. Conclusion: there were a significant number of LAH/LAE, coroner vascular diseases and bundle branch block on DM type 2 patient ECG traces in Policlinic of Endocrine Prof. Dr. R. D. Kandou Manado hospital.

Keywords: DM type 2, CVD, ECG.
\end{abstract}

\begin{abstract}
Abstrak: Ada begitu banyak teori dan hipotesis tentang hubungan antara DM tipe 2 dan penyakit kardiovaskular (PKV). 5,1 juta kematian akibat DM (3/4 terkait dengan PKV sebagai komplikasi dari DM). Diagnosis dini untuk PKV pada DM tipe 2 sangat penting, seperti gambaran EKG. Populasi penelitian didapatkan dari kunjungan pasien DM tipe 2 di Poliklinik Endokrin BLU RSUP Prof. Dr. R. D. Kandou Manado selama 1 bulan (September 2014). Penelitian di menggunakan desain deskriptif retrospektif terdiri dari rekam medis pasien DM tipe 2 dengan rekam EKG yang dipilih secara non-random. Kami mengevaluasi kelainan EKG pada pasien DM tipe 2. Selama penelitian, ditemukan 53 gambaran LAH/LAE, gangguan pembuluh darah koroner 41 gambaran (18 gambaran iskemik miokard, 23 gambaran infark miokard lama) , blokade cabang berkas 33 gambaran (12 gambaran LAHB / LAFB, 7 gambaran RBBB, 3 gambaran RBBB lnkomplit , 1 gambaran LBBB), dan 9 gambaran LVH. Simpulan: Ditemukan sejumlah besar gambaran EKG untuk LAH/LAE, pembuluh darah koroner, dan blokade cabang berkas pada pasien DM tipe 2 di Poliklinik Endokrin BLU RSUP Prof. Dr, R. D. Kandou Manado.
\end{abstract}

Kata kunci: DM tipe 2, PKV, EKG.

Diabetes melitus (DM) adalah sekelompok penyakit metabolik yang ditandai dengan hiperglikemia akibat defek pada sekresi insulin, kerja insulin, atau keduanya. hiperglikemia kronik dari diabetes berhubungan dengan kerusakan jangka panjang, disfungsi dan kegagalan berbagai organ, terutama mata, ginjal, saraf , jantung dan pembuluh darah. DM terbagi menjadi 4 tipe yang didasarkan etiologinya yaitu DM 
tipe 1, DM tipe 2, DM gestasional, DM tipe spesifik lainnya. Dimana DM tipe 2 merupakan $90-95 \%$ pada populasi. ${ }^{1}$

Menurut International Diabetes Federation (IDF), angka penderita yang tercatat pada tahun 2013 di seluruh dunia kurang lebih 382 juta orang hidup dengan DM yang mana $44 \%$ belum terdiagnosis dan diperkiran pada tahun 2035 akan meningkat sebesar 55\% menjadi 592 juta orang. Populasi terbesar penderita DM berada di bagian pasifik barat, termasuk Indonesia di populasi ini. Angka prevalensinya berjumlah sekitar sekitar 138 juta orang. Indonesia sendiri termasuk negara yang masuk 10 besar negara dengan penderita DM tertinggi di dunia yaitu pada peringkat tujuh setelah Rusia dan Meksiko. Angka penderita DM tercatat 8,5 juta orang, mayoritas 382 juta orang yang menderita DM tersebut berumur kisaran 40 - 59 tahun dan 80\% ada di negara dengan pendapatan menengah kebawah atau negara berkembang terutama di daerah urban. Di tahun 2013 tercatat, DM menyebabkan 5,1 juta meninggal. Artinya tiap enam detik satu orang meninggal karena DM. ${ }^{2}$

Salah satu penyebab mortalitas tersering pada penderita DM adalah penyakit kardiovaskular (PKV). Menurut WHO pada tahun 2008, kematian akibat PKV pada penderita DM di Indonesia mencapai 400 per 100.000 orang pada lakilaki dan 300 per 100.000 orang pada perempuan dan angka tersebut terus meningkat dari tahun ke tahun. ${ }^{15}$ Data dari penelitian klinis menunjukan lebih dari tigaperempat pasien DM dengan PKV yang meninggal penyebabnya dikaitkan dengan aterosklerosis, sebagian besar kasus (75\%) karena penyakit jantung koroner (PJK). ${ }^{3}$

Menurut beberapa hipotesis, DM tipe 2 secara garis besar melalui beberapa mekanisme dapat memicu inflamasi pada pembuluh darah, peningkatan pembentukan trombus, dan vasokonstriksi. Yang secara keseluruhan dapat mendorong aterosklerosis sehingga terjadi penyakit jantung koroner, iskemik miokard dan berujung pada gagal jantung. Namun pada pasien DM iskemia miokard sering tanpa keluhan (silent) dan jika menunjukan manifestasi klinis sering sudah dalam keadaan lanjut. ${ }^{3}$ Sehingga diagnosis untuk PKV harus ditegakan sejak dini untuk mengurangi mortalitas serta menentukan rencana tatalaksana.

Diperlukan alat diagnosis dini PKV dengan tingkat akurasi yang baik, cepat, nyaman untuk pasien, tersedia diberbagai pusat pelayanan kesehatan di Indonesia dan mudah dijangkau oleh semua kalangan. Salah satunya adalah Elektrokardiogram (EKG). ${ }^{4}$ EKG adalah alat penunjang diagnosis yang merekam sebagian kecil aktivitas listrik yang dihasilkan oleh otot jantung selama depolarisasi dan repolarisasi. Aktivitas listrik itu menyebar ke jaringan sekitar jantung dan dihantarkan melalui cairan tubuh hingga mencapai permukaan tubuh dan direkam oleh elektroda perekam dari EKG ${ }^{4}$ sehingga dapat memberikan data yang mendukung diagnosis serta pada beberapa kasus penting untuk penatalaksanaan pasien. $^{5}$ Pada komplikasi makrovaskular DM, terjadi kekurang suplai $\mathrm{O}_{2}$ di sel otot jantung akibat penurunan aliran darah ke otot jantung sehingga terjadi penurunan pembentukan energi kemudian gangguan pertukaran ion untuk depolarisasi dan repolarisasi yang semuanya berujung pada gangguan kontraksi otot jantung. karena aktivitas mekanis dipicu oleh aktivitas listrik, disinilah EKG berperan untuk mengevaluasi dan memberikan informasi mengenai status jantung. ${ }^{6}$

$$
\text { Kegunaan EKG pada bidang }
$$
kardiologi dapat digunakan untuk mendiagnosis hal-hal berikut ini seperti sudut kelistrikan jantung, monitoring denyut jantung, aritmia, kelainan urutan aktivasi jantung, peningkatan ketebalan dan ukuran otot jantung atrium dan ventrikel, iskemik dan infark miokard, efek obat, karditis, monitoring pemacu jantung. ${ }^{7}$ Menurut sebuah literatur dikatakan bahwa EKG juga bisa digunakan dalam mengidentifikasi PKV pada diabetes, seperti silent ischemia miocardial, neuropati autonomi jantung, kardiomiopati diabetik. ${ }^{8}$ Meskipun EKG memiliki tingkat 
akurasi 58,2-62\% jika dibandingkan dengan angiografi koroner dalam mendiagnosis PKV terutama PJK dan alat pemeriksaan penunjang utama dalam kardiomiopati diabetik adalah ekokardiografi, namun jika didasarkan pada ketersediaan alat dan jangkauan ekonomi masyarakat menengah kebawah, EKG cukup bisa diandalkan dalam penegakan diagnosis $\mathrm{PKV}{ }^{4}$

\section{METODE PENELITIAN}

Jenis penilitian yang digunakan dalam penelitian ini adalah penelitian deskriptif dengan pendekatan retrospektif. Penelitian ini dilakukan di Poliklinik Endokrin BLU RSUP Prof. Dr. R. D. Kandou pada bulan oktober-Desember 2014. Sampel penelitian yang diambil adalah rekam medis EKG pasien DM tipe di poliklinik Endokrin BLU RSUP Prof. R.D. Kandou Manado Selama 1 bulan (September 2014) dengan kriteria inklusi ialah Pasien diabetes melitus tipe 2 rawat \& Kriteria eksklusi sebagai berikut: pasien dengan riwayat penyakit jantung bawaan, Pasien dengan karditis, Pasien DM tipe lain (DM tipe 1 dan DM gestasional). Setelah data di kumpulkan, data diolah dan disajikan dengan cara mendeskripsikan hasil temuan data gambaran EKG yang ditemukan serta frekuensi masing-masing temuan.

\section{HASIL PENELITIAN}

Berdasarkan hasil penelitian yang dilakukan terhadap rekam medis EKG pasien DM tipe 2 rawat jalan di Poliklinik Endokrin BLU RSUP Prof. Dr. R. D. Kandou Manado pada periode bulan September 2014 diperoleh rekam medis pasien DM tipe 2 yang memenuhi kriteria inklusi sebanyak 158 orang dari 634 orang.

\section{BAHASAN}

Berdasarkan data yang diperoleh dari rekam medis menunjukan pasien yang didiagnosa DM tipe 2 dengan rekaman EKG pada periode bulan September 2014 di Poliklinik Endokrin BLU RSUP Prof. Dr. R.D. Kandou Manado ialah sebanyak
Tabel 1. Distribusi pasien DM tipe 2 dengan rekam medis EKG berdasarkan umur

\begin{tabular}{ccc}
\hline $\begin{array}{c}\text { Kelompok umur } \\
\text { (tahun) }\end{array}$ & $\begin{array}{c}\text { Jumlah pasien } \\
\text { DM } \\
\text { (n) }\end{array}$ & $\begin{array}{c}\text { Persentase } \\
\text { (\%) }\end{array}$ \\
\hline$<40$ & 2 & 1,3 \\
$40-49$ & 17 & 10,8 \\
$50-59$ & 64 & 40,5 \\
$60-69$ & 59 & 37,3 \\
$>70$ & 16 & 10,1 \\
\hline Jumlah & 158 & 100 \\
\hline
\end{tabular}

Tabel 2. Distribusi pasien DM tipe 2 dengan rekam medis EKG berdasarkan jenis kelamin

\begin{tabular}{ccc}
\hline $\begin{array}{c}\text { Jenis elamin } \\
\text { pasien }\end{array}$ & $\begin{array}{c}\text { Jumlah } \\
\text { pasien DM } \\
(\mathrm{n})\end{array}$ & $\begin{array}{c}\text { Persentase } \\
(\%)\end{array}$ \\
\hline Laki-laki & 50 & 31,6 \\
Perempuan & 108 & 68,4 \\
\hline Jumlah & 158 & 100 \\
\hline
\end{tabular}

Tabel 3. Distribusi Berdasarkan Interpretasi Gambaran EKG

\begin{tabular}{ccc}
\hline \multicolumn{2}{c}{ Jumlah } & Persentas \\
Gambaran EKG & $\begin{array}{c}\text { earan } \\
\text { EKG }\end{array}$ & $\begin{array}{c}\text { e } \\
\text { galam batas normal }\end{array}$ \\
\hline Danguan konduksi jantung & 51 & 25 \\
\hline $\begin{array}{c}\text { Gangguade cabang berkas } \\
\text { Jantung }\end{array}$ & 23 & 11,3 \\
Aritmia kordis & 6 & 2,9 \\
Repolarisasi dini & 1 & 0,5 \\
Elektrolit imbalans & 3 & 1,5 \\
\hline Gangguan vaskular koroner & & \\
Penyakit jantung iskemik & 18 & 8,8 \\
Infark miokard lama & 28 & 13,7 \\
\hline Pembesaran jantung & & \\
LAH/LAE & 53 & 26 \\
RAH & 1 & 0,5 \\
Lenebalan otot jantung & & \\
LVH & 9 & 4,4 \\
\hline Gangguan irama & & 1 \\
Sinus bradikardi & 2 & 4,4 \\
Sinus takikardi & 9 & 100 \\
\hline Jumlah & 204 & \\
\hline
\end{tabular}

158 orang dari 634 pasien DM tipe 2 yang melakukan kunjungan pada bulan September.

Distribusi pasien DM tipe 2 dengan gambaran EKG left atrium hypertrophy/left 
atrium enlargement ditemukan sebanyak 53 gambaran (26\%). Pada sebuah penelitian dikatakan bahwa Pengukuran dengan Cardiac magnetic resonance imaging (CMR) pada struktur dan fungsi atrium kiri adalah prediktif untuk PKV pada populasi pasien diabetes multi-etnik yang tidak ada gejala PKV pada dasarnya. ${ }^{9}$ Belum ada penelitian yang menyebutkan jika gambaran EKG LAH/LAE juga prediktif untuk PKV dan Masih belum jelas hubungan antara banyaknya gambaran EKG LAH/LAE dan DM, apakah berhubungan dengan kardiomiopati diabetik atau tidak.

American Diabetes Association (ADA) dan American Heart Association (AHA) mengeluarkan rekomendasi baru yang menyebutkan DM dianggap sebagai coronary artery diseases risk equivalent dibandingkan dengan faktor risiko lain. ${ }^{10}$ Penelitian lain didapatkan kenyataan bahwa angka kejadian aterosklerosis lebih tinggi pada pasien DM dibandingkan populasi non DM, pasien DM mempunyai risiko tinggi mengalami trombosis, penurunan fibrinolisis dan peningkatan respons inflamasi, dan paa pasien DM terjadi glikosilasi protein yang akan mempengaruhi integritas dinding pembuluh darah. ${ }^{11}$ Berdasarkan penelitian oleh Juutilainen A. dkk di Finlandia. Dilakukan follow-up kepada 1373 pasien non diabetes dan 1059 didapatkan bahwa DM tanpa infark miokard sebelumnya dan Pasien non DM dengan infark miokard sebelumnya mengindikasikan risiko yang sama untuk kematian akibat CHD pada laki-laki maupun perempuan. Namun, diabetes tanpa bukti CHD apapun terlebih dahulu (infark miokard atau angina pektoris atau iskemik pada perubahan EKG) mengindikasikan risiko lebih tinggi dibandingkan dengan adanya bukti CHD terlebih dahulu pada subjek non-diabetes. Risiko ini meningkat terutama pada perempuan. ${ }^{12}$ Penyebab aterosklerosis pada pasien DM tipe 2 bersifat multifaktorial, melibatkan interaksi kompleks dari berbagai keadaan seperti hiperglikemia, hiperlipidemia, stres oksidatif, penuaan dini, hiperinsulinemia dan / atau hiperproinsulinemia serta perubahan-perubahan dalam proses koagulasi dan fibrinolisis. Yang mana aterosklerosis di arteri koroner akan mempersempit pembuluh darah dan menyebabkan berkurangnya suplai darah ke otot jantung dan menyebabkan iskemik. Melalui mekanisme yang kompleks, peningkatan respons Inflamasi dan perubahan-perubahan dalam proses koagulasi dan fibrinolisis memicu terjadinya ruptur plak aterosklerotik dan menyumbat a. koroner sehingga terjadi infark miokardium. ${ }^{11}$ Dari peneltian sebelumnya diatas sesuai dengan temuan pada penelitian ini. Gambaran EKG berupa iskemik maupun infark yang cukup tinggi yaitu iskemik sebanyak 18 gambaran $(8,8 \%)$ dan infark miokard lama (OMI) sebanyak 28 gambaran (13,7\%) dari 204 gambaran EKG yang ditemukan dengan berbagai lokasi iskemik maupun infark.

Beberapa penelitian membuktikan adanya hubungan antara DM dan left ventricle hypertrophy (LVH). The Strong Heart Study (SHS) melaporkan terjadi peningkatan massa ventrikel kiri dan ketebalan dinding ventrikel baik pada perempuan maupun laki-laki dengan DM. temuan yang sama juga dilaporkan pada The Cardiovaskular Heart Study (CHS) dan The Multi-Ethnic Study of Atherosclerosis (MESA). Studi terbaru pada pasien DM tipe 2 di Jepang, melaporkan adanya hubungan antara resistensi insulin, kekakuan arteri dan indeks massa ventrikel kiri (menggunakan cardiac MRI). Temuan ini juga didukung oleh penelitian dengan jumlah sampel yang lebih besar di Swedia yang menunjukan adanya hubungan antara sindrom metabolik, resistensi insulin, dan peningkatan massa dan ketebalan dinding ventrikel. ${ }^{13}$ Namun, pada penelitian yang dilakukan di Poliklinik Endokrin BLU RSUP Prof. Dr. R. D. Kandou Manado pada bulan September 2014 ini ditemukan hanya 9 dari 204 temuan (4,4\%) yang menunjukan gambaran LVH. Tidak signifikannya gambaran LVH pada penelitian ini mungkin disebabkan oleh 
kurangnya sampel penelitian.

Gangguan konduksi jantung (RBBB, RBBB Inkomplit, LBBB, LAHB/LAFB) ditemukan pada 23 gambaran (11,3\%). Pada penelitian yang dilakukan oleh Stern S. dan Sclarowsky S. ditemukan adanya pemanjangan interval QT dan dispersi QT bahkan pada awal onset dari DM. ${ }^{8}$ Pada sebuah review artikel yang oleh Movahed MR disebutkan bahwa ada beberapa penelitian non-randomized yang melaporkan terjadi peningkatan prevalensi blokade konduksi jantung pada pasien DM, seperti right bundle branch block (RBBB), bifascicular block dan high degree atrioventricular (AV) block tapi tidak dengan left bundle branch block (LBBB). Penyebab dari blokade konduksi jantung pada pasien DM masih belum diketahui. ${ }^{14}$

\section{SIMPULAN}

Ditemukan sejumlah besar gambaran EKG untuk LAH/LAE, pembuluh darah koroner, dan blokade cabang berkas pada pasien DM tipe 2 di Poliklinik Endokrin BLU RSUP Prof. Dr, R. D. Kandou Manado.

\section{SARAN}

Anjuran untuk pemeriksaan EKG tiap beberapa bulan sekali atau minimal sekali dalam setahun pada pasien DM tipe 2 untuk mengetahui PKV sedini mungkin pada pasien DM tipe 2 mengingat tingginya risiko PKV pada pasien DM serta disarankan kepada petugas rekam medis untuk penyusunan rekam medis lebih profesional dan data pasien yang lebih lengkap agar mempermudah pengambilan data untuk penelitian lebih lanjut.

\section{UCAPAN TERIMA KASIH}

Ucapan terima kasih disampaikan kepada dr. A. Lucia Panda, SpPD, SpJP(K) dan dr. Cerelia Sugeng, SpPD selaku dosen penguji skripsi yang telah memberikan kritikan dan saran, serta semua pihak baik secara langsung maupun tidak langsung, yang telah memberikan ide dan gagasan kepada penulis dalam menyelesaikan artikel ini.

\section{DAFTAR PUSTAKA}

1. American Diabetes Association. Diagnosis and classification of diabetes mellitus. 2014 [citied 2014 Okt 9]. Available from:

http://care.diabetesjournals.org/content/ 37/Supplement_1/S81.full

2. Cho N, Whiting $D$, Guariguata $L$, Montoya P, Forouhi N, Hambleton I, et al. IDF diabetes atlas. $6^{\text {th }}$ Edition. International Diabetes Federation; 2013. p. 9.

3. Alwi I. Tatalaksana Holistik Penyakit Kardovaskular. $2^{\text {nd }}$ Edition. Jakarta: Interna publishing; 2012. p.11-25.

4. Mahmoodzadeh S, Moazenzadeh $M$, Rashidinejad $\mathrm{H}$, and Sheikhvatan $\mathrm{M}$. Diagnostic performance of electrocardiography in the assessment of significant coronary artery disease and its anatomical size in comparison with coronary angiography. J Res Med Sci. 2011;16(6):750-5.

5. Hampton JR. Apa itu EKG. In: Wahab AS, Rini C, Dian R,Wahyu S, editors. Dasar-Dasar EKG. $6^{\text {th }}$ Edition. Jakarta: Penerbit Buku Kedokteran EGC; 2006. p. 1-27.

6. Sherwood L. Fisiologi Jantung. In: Pendit BU, Yesdelita N, editors. Fisiologi Manusia: Dari Sel ke Sistem. Jakarta: EGC; 2013. p 327-67.

7. Malmivuo J, Plonsey R. Basis of ECG. Bioelectromagnetism: Principles and Applications of Bioelectric and Biomagnetic Fields. New York: Oxford University Press; 1995. p.19.

8. Stern S, Sclarowsky S. The ECG in diabetes melitus. Circulation. 2009 [cited 2014 Sep 9];120:1633-6. Avaliable from: http://circ.ahajournals.org.

9. Markman MT, Habibi M, AmbaleVenkatesh B, Zareian M, Wu C, Heckbert RS, et al. Left atrial structure and function and cardiovascular events in patients with diabetes mellitus: results from multiethnic study of atherosclerosis (MESA), Circulation. 2014;130:A12226.

10.Alwi I. Tatalaksana holistik penyakit kardovaskular. $2^{\text {nd }}$ Edition. Jakarta: Interna publishing; 2012. p. 1-10.

11.Shahab A. Komplikasi Kronik DM: 
Penyakit Jantung Koroner, In: Setiati S, Alwi I, Sudoyo AW, Simadibrata M, Setiyohadi B, Syam AR, editors. Buku Ajar Ilmu Penyakit Dalam. 6th Edition. Jakarta: Interna Publishing; 2014. p. 2414-9.

12.Juutilainen A, Lehto $S$, Rönnemaa $T$, Pyörälä K, Laakso M. Type 2 Diabetes As a "Coronary Heart Disease Equivalent": an 18-year prospective population-based study in Finnish subjects. Diabetes Care. 2005 Dec;28(12):2901-7.

13.Shahab A. Kardiomiopati diabetik, In: Setiati S, Alwi I, Sudoyo AW,
Simadibrata M, Setiyohadi B, Syam AR, editors. Buku Ajar Ilmu Penyakit Dalam. 6th Edition. Jakarta: Interna Publishing; 2014. p. 2408-13.

14. Movahed MR. Diabetes as a risk factor for cardiac conduction defects: a review. Diabetes Obes Metab. 2007 May;9(3):276-81.

15. Cardiovascular diseases and diabetes, deaths per $\quad 100 \quad 000$ Data by country. 2012 [cited 2014 Oct 23]. Available from: http://apps.who.int/gho/data/node.main. A865?lang=en. 